\title{
HUBUNGAN KARAKTERISTIK SUAMI DENGAN KEIKUTSERTAAN SUAMI MENJADI AKSEPTOR KELUARGA BERENCANA DI WILAYAH DESA KARANGDUWUR KECAMATAN PETANAHAN KABUPATEN KEBUMEN JAWA TENGAH
}

\author{
Hesti Wahyu Maharyani, Sri Handayani \\ Fakultas Kesehatan Masyarakat, Universitas Ahmad Dahlan, Yogyakarta
}

\begin{abstract}
Background : Family planning program is a program intended to help couples and individuals achieve their reproductive goals. The low participation of men in family planning can have negative impact on women's reproductive health because of not only women are always actively involved, so women emancipation who demanded equality of rights between men and women becomes a reality. The purpose of this study is to determine the relationship between the characteristics of the husband with the participation of husbands become acceptors of family planning in the Village area Karangduwur Petanahan Kebumen district of Central Java.

Methods : This was a observasional analytic research using cross sectional research design in this study were all husbands of childbearing age (EFA) in the Village Karangduwur Petanahan Kebumen district of Central Java. The number of samples taken in this study is 85 people. Data analysis was performed univariate and bivariate.

Result : Result of hypothesis test showed that husband characteristic in terms of revenue associated with the participation of husbands in family planning as indicated by the value of Chi Square $=7.743$ $(p=0.005<0.05)$, husband characteristic in terms of knowledge is not related to the participation of husbands in family planning as indicated by the value Chi Square $=0.022(p=0.882>0.05)$, characteristic husband in terms of education is not related to the participation of husbands in family planning as indicated by the value of Chi Square $=2.292(p=0.130>0.05)$, husband characteristic in terms of number of children associated with the participation of husbands in family planning as indicated by the value of Chi Square $=10.916(p=0.01<0,05)$.

Conclusion : From four independent variables studied there was a significant correlation factors there are income, and number of children, or parity, and there was no significant correlation: education and knowledge.
\end{abstract}

Keywords : Husband Participation, Family Planning Program, Acceptor.

\section{PENDAHULUAN}

Program keluarga berencana adalah suatu program yang dimaksudkan untuk membantu para pasangan dan perorangan dalam mencapai tujuan reproduksi mereka, mencegah kehamilan yang tidak diinginkan dan mengurangi insidens kehamilan beresiko tinggi, kesakitan dan kematian membuat pelayanan yang bermutu, terjangkau, diterima dan mudah diperoleh bagi semua orang yang membutuhkan, meningkatkan mutu nasehat, komunikasi, informasi, edukasi, konseling, dan pelayanan meningkatkan partisipasi dan tanggung jawab pria dalam praktek KB. Tanggung jawab pria dalam hal KB sangat penting dalam peranserta program Keluarga Berencana 1.

Pengembangan program KB yang secara resmi dimulai sejak tahun 1970 telah memberikan dampak terhadap penurunan tingkat fertilitas total (TFR) yang cukup menggembirakan, namun partisipasi pria dalam ber KB masih sangat rendah yaitu sekitar 1,3 persen². Angka tersebut bila dibandingkan dengan negara-negara berkembang lainnya seperti pakistan 5,2 persen pada tahun 1999. Banglades 13,9 persen pada tahun 1997, Malaysia 16,8 persen pada tahun 1998 adalah yang 
terendah $^{3}$. Hal ini selain disebabkan oleh keterbatasan macam dan jenis alat kontrasepsi pria, juga oleh keterbatasan pengetahuan suami akan hak-hak dan kesehatan reproduksi serta kesehatan dan keadilan gender.

Berdasarkan jumlah pencapaian peserta KB tersebut Pelaksanaan program keluarga berencana (KB) masih ada yang belum mencapai hasil yang ideal, yaitu di Wilayah Jawa Tengah dimana JaTeng merupakan salah satu penyangga utama program KB di Indonesia, selain Jawa Barat dan Jawa Timur. Jumlah penduduk di tiga provinsi tersebut mencapai setengah jumlah penduduk di Indonesia, atau hampir sama dengan jumlah penduduk di 30 provinsi lainnya. Di karenakan masih sangat minimnya peran aktif pria untuk ber-KB. Dari seluruh peserta KB, hanya dua persen dari kalangan pria. Hal tersebut mengingat masih adanya paradigma di masyarakat, di mana KB hanya menjadi urusan wanita, di samping keterbatasan jenis alat kontrasepsi yang dapat digunakan untuk pria. "Karena itu, program KB di tiga provinsi itu, termasuk Jateng, tidak boleh kendor, tidak boleh goyah, apalagi mundur. Jika salah satunya kendor, program KB akan ambruk ${ }^{4}$.

Berdasarkan penelitian pendahuluan yang dilakukan oleh peneliti maka berdasarkan wawancara yang dilakukan pada pra penelitian terhadap kepala Desa Karang Duwur dan petugas PLKB pada tanggal 2 Mei 2010 maka penduduk pria yang menjadi akseptor KB hanya berkisar 12 orang dari jumlah penduduk usia subur sebanyak 560 PUS. Fenomena rendahnya penduduk pria yang menjadi akseptor KB merupakan gambaran umum yang dianggap dapat mewakili rendahnya partisipasi atau keikutsertaan pria atau suami menjadi akseptor KB. Apabila dilihat dari karakteristik wilayah maka Desa Karang Duwur juga memberikan keterwakilan gambaran pada wilayah pedesaan yang berada di pinggir kota lainnya. Kesamaan karakteristik ini dapat dilihat dari indikator sosial ekonomi, pendidikan, agama, motivasi, dan adat istiadat. Selain itu terdapat pemilihan lokasi karena ketersediaan data yang didapatkan peneliti pada wilayah ini.

Menurut BKKBN ${ }^{1}$, Hambatan keluarga atau istri, juga menjadi penghalang perkembangan partisipasi pria terutama di pedesaan. Sedangkan diperkotaan seperti DKI tidak menjadi masalah. Sekitar $70 \%$ menurut penuturan suami di DIY bahwa istri tidak setuju atau tidak rela suami ikut KB dengan alasan seperti kasihan sama suami, karena mencari nafkah merasa khawatir suami menyeleweng, takut pada efek samping terutama penurunan libido. Dalam hal tersebut penyedia layanan harus menyadari bagaimana faktor-faktor tersebut mempengaruhi pemilihan metode di daerah mereka dan harus memantau perubahan-perubahan yang mungkin mempengaruhi keikutsertaan suami. Berdasarkan uraian di atas, maka penulis ingin mengetahui hubungan karakteristik suami dengan keikutsertaan suami menjadi akseptor keluarga berencana di wilayah Desa Karangduwur Kecamatan Petanahan Kabupaten Kebumen Jawa Tengah.

\section{METODE PENELITIAN}

Penelitian ini merupakan jenis penelitian Observasional analitik dengan rancangan penelitian cross sectional dimana setiap subjek penelitian hanya akan dilakukan satu kali pengukuran terhadap status karakter atau variabel subjek pada saat yang bersamaan ${ }^{5}$. Tempat Penelitian ini akan dilaksanakan di Desa Karangduwur Kecamatan Petanahan Kabupaten Kebumen pada bulan Juli 2010. Populasi dalam penelitian ini adalah semua suami usia subur (PUS) di Desa Karangduwur Kecamatan Petanahan Kabupaten Kebumen Jawa Tengah. Sampel adalah bagian dari populasi yang merupakan wakil dari populasi. Pengambilan sampel ini dilakukan melalui teknik sampel random sampling, yaitu pengambilan sampel dari anggota populasi dilakukan secara acak tanpa memperhatikan strata yang ada dalam populasi itu. Untuk 
mendapatkan jumlah sampel menggunakan perhitungan dengan rumus sebagai berikut:

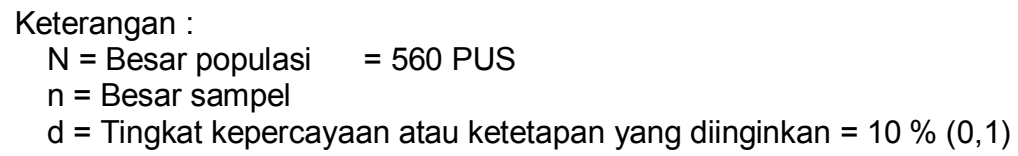

\section{HASIL PENELITIAN DAN PEMBAHASAN}

\section{a. Hasil Penelitian}

Tempat penelitian ini adalah di Desa Karangduwur Kecamatan Petanahan Kabupaten Kebumen Provinsi Jawa Tengah di mana desa ini terdiri dari enam Dusun yaitu Dusun Salak, Wanasingan, Ulekan, Bentaran, Kenyaen, dan Penegar. Jumlah penduduk Desa Karangduwur sampai April 2010 yaitu jumlah laki - laki 2313 jiwa $(52,13 \%)$ dan perempuan 2124 jiwa $(47,87 \%)$ dengan jumlah penduduk Karangduwur Kecamatan Petanahan Kabupaten Kebumen yang sebesar 4437 jiwa. Sampai dengan bulan April 2010 jumlah PUS adalah sebanyak 560 PUS dengan jumlah Akseptor KB sebanyak 452 orang.

1) Analisis Univariat

\begin{tabular}{|c|c|c|}
\hline Usia & Jumlah & $\%$ \\
\hline $15-20$ tahun & 0 & 0 \\
\hline $21-35$ tahun & 47 & 55,3 \\
\hline $36+$ tahun & 38 & 44,7 \\
\hline Jumlah & 85 & 100,0 \\
\hline
\end{tabular}

Berdasarkan tabel di atas diketahui bahwa mayoritas suami berusia 21 35 tahun yaitu sebanyak 47 orang atau 55,3\%. Usia suami hasil penelitian juga menunjukkan bahwa sebagian besar responden masih masuk dalam usia subur. 
Tabel 2. Distribusi Responden berdasarkan Pendidikan di wilayah Desa Karangduwur

\begin{tabular}{|c|c|c|}
\hline Pendidikan & Jumlah & $\%$ \\
\hline SD & 17 & 20,0 \\
\hline SLTP & 26 & 30,6 \\
\hline SLTA & 33 & 38,8 \\
\hline Perguruan tinggi & 9 & 10,6 \\
\hline Jumlah & 85 & 100,0 \\
\hline
\end{tabular}

Berdasarkan tabel di atas mayoritas Suami berpendidikan SLTA, yaitu sebanyak 33 orang atau 38,3\%. Mayoritas pendidikan responden suami adalah SMA yang dikategorikan relatif tinggi, hal ini diharapkan juga bahwa suami dapat lebih berperan dalam ber-KB.

Tabel 3. Distribusi Responden berdasatkan pekerjaan di wilayah DesaKarangduwur

\begin{tabular}{|c|c|c|}
\hline Pekerjaan & Jumlah & $\%$ \\
\hline Buruh & 24 & 28,2 \\
\hline Pedagang & 7 & 8,2 \\
\hline Petani & 17 & 20,0 \\
\hline Swasta & 32 & 37,6 \\
\hline PNS/TNI/Polri & 5 & 5,9 \\
\hline Jumlah & 85 & 100,0 \\
\hline
\end{tabular}

Berdasarkan pekerjaan diketahui bahwa mayoritas suami berprofesi sebagai swasta yaitu sebanyak 32 orang atau $37,6 \%$. Pekerjaan suami mencerminkan status ekonomi keluarga, karena pekerjaan pada masyarakat kita umumnya penyumbang pendapatan rumah tangga utama. Temuan data menyatakan bahwa mayoritas reponden bekerja sebagai swasta, walaupun pekerjaan responden berada pada sektor non informal seperti buruh, petani, wirasawasta dan swasta. Namun pekerjaan tersebut mampu memberikan pendapatan yang mencukupi kebutuhan rumah tangga mereka.

Tabel 4. Distribusi Responden berdasarkan jumlah anak di wilayah Desa Karangduwur

\begin{tabular}{|c|c|c|}
\hline Jumlah Anak & Jumlah & $\%$ \\
\hline 0 & 7 & 8,2 \\
\hline 1 & 26 & 30,6 \\
\hline 2 & 27 & 31,8 \\
\hline$\geq 3$ & 25 & 29,4 \\
\hline Jumlah & 85 & 100,0 \\
\hline
\end{tabular}

Berdasarkan jumlah anak diketahui bahwa mayoritas keluarga memiliki jumlah anak 2 yaitu sebanyak 27 orang atau $31,8 \%$, dengan ini diketahui bahwa keluarga tersebut sudah berhasil mengikuti program KB, oleh karena semakin banyak jumlah anak maka semakin berat beban keluarga dalam menghidupinya. 
Tabel 5. Distribusi responden berdasarkan pendapatan di wilayah Desa Karangduwur

\begin{tabular}{lcc}
\hline Pendapatan & Jumlah & $\%$ \\
\hline$<$ Rp. 650.000,000 & 58 & 68,2 \\
$>$ Rp. 650.000,000 & 27 & 31,8 \\
\hline Jumlah & 85 & 100,0 \\
\hline
\end{tabular}

Berdasarkan pendapatan diketahui bahwa mayoritas keluarga memiliki penghasilan < UMR yaitu sebanyak 58 orang atau 68,2\%. Pengasilan keluarga yang semakin besar akan memudahkan mereka untuk memenuhi segala macam kebutuhan keluarga, salah satunya adalah kebutuhan kesehatan.

Tabel 6. Distribusi responden berdasarkan keikutsertaan suami menjadi akseptor KB di wilayah Desa Karangduwur

\begin{tabular}{lcc}
\hline \multicolumn{1}{c}{ keikutsertaan suami dalam KB } & Jumlah & $\%$ \\
\hline MOP & 3 & 3,5 \\
Kondom & 17 & 20,0 \\
Coitus Interuptus & 4 & 4,7 \\
Tidak Mengunakan & 61 & 71,8 \\
\hline Jumlah & 85 & 100,0 \\
\hline
\end{tabular}

Berdasarkan keikutsertaan suami diketahui bahwa mayoritas responden suami tidak mengikuti KB yaitu sebanyak 61 orang atau 71,8\%. Angka ini sekilas menunjukkan bahwa kesadaran suami untuk mengikuti KB masih rendah.

Tabel 7. Distribus responden berdasarkan pengetahuan di wilayah Desa karangduwur

\begin{tabular}{lcc}
\hline pengetahuan dalam KB & Jumlah & $\%$ \\
\hline Baik & 70 & 82,4 \\
Tidak Baik & 15 & 17,6 \\
\hline Jumlah & 85 & 100,0 \\
\hline
\end{tabular}

Berdasarkan tabel pengetahuan diketahui bahwa mayoritas responden memiliki pengetahuan KB yang tergolong baik yaitu sebanyak 70 orang atau $82,4 \%$.

2 Analisis Bivariat

Hubungan antara karakteristik suami dengan keikutsertaan suami menjadi akseptor keluarga berencana dianalisis dengan metode tabulasi silang (Cross $T a b)$. Tabulasi silang adalah suatu teknik untuk membandingkan dua variabel ${ }^{9}$. 
Tabel 8 . Tabulasi Silang antara Pendidikan dan Keikutsertaan Suami menjadi Akseptor KB di wilayah Desa Karangduwur

\begin{tabular}{lcccc}
\hline Pendidikan & \multicolumn{2}{c}{ Keikutsertaan Suami } & Total & $P$ value \\
& Tidak & Ya & & \\
\cline { 2 - 3 } & $\mathrm{n}$ & $\mathrm{n}$ & & \\
\hline Rendah & 34 & 9 & 43 & 0,130 \\
Tinggi & 27 & 15 & 42 & \\
\hline Total & 61 & 24 & 85 & \\
\hline
\end{tabular}

Berdasarkan tabel hasil sebaran pendidikan diketahui bahwa sebagian besar responden yang memiliki pendidikan yang rendah, cenderung untuk tidak mengikuti KB. Hasil uji chi square menunjukkan bahwa karakteristik suami dalam hal pendidikan tidak berhubungan dengan keikutsertaan suami dalam KB yang ditunjukkan dengan nilai Chi Square $=2,292(p=0,130>0,05)$.

Tabel 9. Tabulasi Silang antara Jumlah Anak dan Keikutsertaan Suami menjadi Akseptor KB di wilayah Desa Karangduwur

\begin{tabular}{lccccc}
\hline & \multicolumn{2}{c}{ Keiutsertaan Suami } & & \\
\cline { 2 - 3 } & Jumlah Anak & Tidak & Ya & Total & P value \\
\cline { 2 - 3 } & $\mathrm{n}$ & $\mathrm{n}$ & $\mathrm{n}$ & \\
\hline Sedikit & 17 & 16 & & 33 & \multirow{2}{*}{0,001} \\
Banyak & 44 & 8 & & 52 & \\
\hline Total & 61 & 24 & & 85 & \\
\hline
\end{tabular}

Berdasarkan tabel dapat diketahui bahwa sebagian besar responden yang memiliki jumlah anak yang banyak, cenderung untuk tidak mengikuti KB. Hasil uji chi square menunjukkan bahwa karaktristik suami dalam hal jumlah anak berhubungan dengan keikutsertaan suami dalam KB yang ditunjukkan dengan nilai Chi Square $=10,916(p=0,001<0,05)$.

Tabel 10. Tabulasi Silang antara Pendapatan dan Keikutsertaan Suami menjadi Akseptor KB di Wilayah Desa Karangduwur

\begin{tabular}{lccccc}
\hline & \multicolumn{2}{c}{ Keiutsertaan Suami } & & \\
\cline { 2 - 3 } Pendapatan & Tidak & & Total & P value \\
\cline { 2 - 3 } & $\mathrm{n}$ & $\mathrm{n}$ & $\mathrm{n}$ & \\
\hline Sedikit & 47 & 11 & & 58 & \\
Banyak & 14 & 13 & & 27 & 0,005 \\
\hline Total & 61 & 24 & & 85 & \\
\hline
\end{tabular}

Berdasarkan tabel dapat diketahui bahwa sebagian besar responden yang pendapatannya di bawah Rp. 650.000 , cenderung untuk tidak mengikuti KB. Hasil uji chi square menunjukkan bahwa karaktristik suami dalam hal pendapatan berhubungan dengan keikutsertaan suami dalam KB yang ditunjukkan dengan nilai Chi Square $=7,743(p=0,005<0,05)$. 
Tabel 11. Tabulasi Silang antara Pengetahuan dan Keikutsertaan Suami Menjadi Akseptor KB di Wilayah Desa Karangduwur

\begin{tabular}{|c|c|c|c|c|c|}
\hline \multirow{6}{*}{$n=\frac{}{1+N(d)^{2}}$} & \multirow[t]{3}{*}{ Pengetahuan } & \multicolumn{2}{|c|}{ Keiutsertaan Suami } & \multirow{3}{*}{$\begin{array}{c}\text { Total } \\
\mathrm{n}\end{array}$} & \multirow{3}{*}{$P$ value } \\
\hline & & Tidak & $\mathrm{Ya}$ & & \\
\hline & & $\mathrm{n}$ & $\mathrm{n}$ & & \\
\hline & Baik & 50 & 20 & 70 & \\
\hline & Tidak Baik & 11 & 4 & 15 & 0,882 \\
\hline & Total & 61 & 24 & 85 & \\
\hline
\end{tabular}

Berdasarkan tabel di atas dapat diketahui bahwa sebagian besar responden yang memiliki pengetahuan yang baik,justru cenderung untuk tidak mengikuti KB. Hasil uji chi square menunjukkan bahwa karaktristik suami dalam hal pengetahuan tidak berhubungan dengan keikutsertaan suami dalam KB yang ditunjukkan dengan nilai Chi Square $=0,022(p=0,882>0,05)$.

\section{Analisis Multivariat}

Analisis multivariat digunakan untuk mengetahui pengaruh antara pendidikan, jumlah anak, pengetahuan dan penghasilan terhadap partisipasi suami dalam KB. Analisis multivariat menggunakan uji statistik regresi linear dengan persamaan:

$$
Y=a+b X_{1}+b X_{2}+b X_{3}+b X_{4}
$$

Tabel 12. Hasil Analisis Multivariat

\begin{tabular}{|c|c|c|c|c|c|c|}
\hline \multirow[t]{2}{*}{ Model } & & \multicolumn{2}{|c|}{$\begin{array}{l}\text { Unstandardized Coeffi- } \\
\text { cients }\end{array}$} & \multirow{2}{*}{$\begin{array}{c}\begin{array}{c}\text { Standardized } \\
\text { Coefficients }\end{array} \\
\text { Beta }\end{array}$} & \multirow{2}{*}{$\mathrm{t}$} & \multirow{2}{*}{$\operatorname{sig}$} \\
\hline & & B & Std. Error & & & \\
\hline & (Constant) & ,295 & ,269 & & 1,100 & 275 \\
\hline $\mathrm{X} 1$ & Pendidikan & 049 &, 090 &, 054 &, 539 &, 591 \\
\hline $\mathrm{X} 2$ & Jumlah anak &, 350 &, 092 &,- 379 & $-3,785$ &, 000 \\
\hline $\mathrm{X} 3$ & Pendapatan &, 315 &, 096 &, 326 & 3,296 &, 001 \\
\hline $\mathrm{X} 4$ & Pegetahuan KB &, 054 & ,116 &, 046 & ,464 & 644 \\
\hline
\end{tabular}

Berdasarkan tabel di atas dapat diketahui bahwa hanya X2 (Jumlah anak) dan X3 (Pendapatan) yang memiliki nilai sig. (p) yang $<0,05$ dari Karakteristik Suami maka dapat disimpulkan bahwa X2 (Jumlah anak) dan X3 (Pendapatan) berpengaruh secara signifikan terhadap keikutsertaan suami dalam ber KB. Variable yang paling berpegaruh di antara X2 (Jumlah anak) dan X3 (Pendapatan) adalah variable jumlah anak yang berpengaruh secara negatif dan signifikan. Hal ini ditunjukkan oleh koefisien regresi terstadarisasi yang paling besar serta $p$ terkecil dibandingkan yang lain. 


\section{b. Pembahasan}

Hasil uji statistik hubungan karakteristik suami dalam hal pendidikan dengan keikutsertaan suami dalam KB didapat bahwa tidak berhubungan dengan keikutsertaan suami dalam KB yang ditunjukkan dengan nilai Chi Square $=2,292(p$ $=0,130>0,05)$. Pendidikan adalah upaya untuk memberikan pengetahuan sehingga terjadi perubahan perilaku positif yang meningkat. Tingkat pendidikan menunjukkan korelasi dengan terjadinya perubahan perilaku positif yang meningkat dan dengan demikian pengetahuan juga meningkat. Pendidikan merupakan tingkat dasar pengetahuan yang dimilki seseorang ${ }^{6}$. Hasil penelitian yang menunjukkan rendahnya keikutsertaan suami dalam hal pendidikan suami, dikarenakan pendidikan suami tidak secara langsung dengan pengetahuan. Pengetahuan adalah aspek kognitif pada diri manusia, sebelum menjadi suatu kegiatan yang sifatnya motorik pengetahuan akan mempengaruhi sisi afektif atau sikap pada diri manusia. Oleh karena itu pendidikan yang tinggi belum tentu pengetahuannya akan tinggi pula, akibatnya keikutsertaan suami dalam ber KB juga belum tentu baik sebagaimana kondisi pendidikan suami. Bila ditinjau dari segi pendidikan, menurut hasil analisis lanjut SDKI $1997^{7}$ ternyata "pendidikan"berpengaruh negatif terhadap pemakaian vasektomi, sementara wilayah (desa) memberikan pengaruh positif. Mereka yang berpendidikan tinggi cenderung memilih kondom.

Keluarga Berencana (KB) adalah cara merencanakan keluarga: Kapan ingin mendapatkan anak dan berapa jumlah anak. Bila memutuskan untuk menunggu untuk mendapatkan keturunan, maka bisa memilih beberapa cara untuk menunda kehamilan dengan kontrasepsi ${ }^{8}$. Hubungan antara jumlah anak dengan keikutsertaan suami dalam KB memiliki hubungan yang erat karena dalam program $\mathrm{KB}$ itu sendiri jumlah anak merupakan salah satu tujuan dalam program KB.

Karakteristik suami dalam hal jumlah anak berhubungan dengan keikutsertaan suami dalam KB yang ditunjukkan dengan nilai Chi Square $=10,916$ ( $p=$ $0,001<0,05)$. Hal ini dikarenakan jumlah anak yang dimiliki keluarga sebagian besar sudah direncanakan dan dibicarakan antara suami dan istri berdasarkan berbagai pertimbangan seperti kondisi kesehatan suami dan istri, serta kesiapan mental dan kemampuan ekonomi untuk menjamin kesehatan, pendidikan dan masa depan anak - anaknya khususnya untuk jumlah anak 2 orang. Hasil penelitian ini didukung pernyataan Siswosudarmo bahwa sesuai dengan Program Norma Keluarga Kecil Bahagia Sejahtera (NKKBS) menganjurkan setiap pasangan keluarga hanya mempunyai dua anak saja (catur warga).

Hasil uji statistik menunjukkan bahwa karakteristik suami dalam hal pendapatan berhubungan dengan keikutsertaan suami dalam KB yang ditunjukkan dengan nilai Chi Square $=7,743(p=0,005<0,05)$. Pendapatan keluarga mencerminkan kondisi kemampuan ekonomi suatu keluarga, pendapatan menengah tinggi cenderung untuk lebih berpartisipasi dalam KB dibandingkan pendapatan rendah. Bila ditinjau dari kondisi sosial ekonomi, hasil studi Pusat Kajian Pembangunan Atmajaya bekerjasama dengan Puslitbang Biomedis \& Reproduksi di DKI Jakarta (1999), menyatakan bahwa tingkat pendapatan suatu keluarga sangat berpengaruh terhadap kesertaan suami dalam ber-KB.

Hasil uji statistik Karakteristik suami dalam hal pengetahuan diketahui tidak berhubungan dengan keikutsertaan suami dalam KB yang ditunjukkan dengan nilai Chi Square $=0,022(p=0,882>0,05)$. Tingkat pengetahuan yang baik akan lebih mendorong seseorang untuk bertindak, tidak terkecuali dalam ber-KB pengetahuan suami mengenai KB akan lebih memberikan dorongan kepadanya untuk berpartisipasi. Dari pengamatan berbagai survei di beberapa propinsi, tingkat pengetahuan pria terhadap keluarga berencana secara umum terlihat masih rendah, 
berbagai faktor yang mempengaruhi antara lain pendidikan, pekerjaan, keterpaparan media masa, kondisi lingkungan, pengalaman menggunakan alat kontrasepsi dan faktor-faktor lainnya.

Namun pengetahuan suami dalam ber KB yang baik tidak otomatis membuat kesertaan suami menjadi baik pula. Pada ranah psikomotorik atau pelaksanaan partisipasi, suami masih banyak mempertimbangkan hal lain sebelum ikut berpartisipasi dalam KB seperti kesenjangan gender dan lain sebagainya. Faktor penyebab lain dari rendahnya keikutsertaan suami dalam ber KB adalah karena partisipasi suami dalam ber KB di lokasi penelitian menunjukkan kecenderungan yang sama untuk setiap kelompok pngetahuan, baik kelompok pengetahuan rendah maupun pngetahuan tinggi mayoritas tidak ikutserta untuk menjadi akseptor dalam $\mathrm{KB}$.

\section{SIMPULAN DAN SARAN}

\section{a. Simpulan}

Berdasarkan analisis hasil penelitian dan pembahasan pada penelitian ini maka dapat diambil kesimpulan sebagai berikut:

1) Tidak ada hubungan yang signifikan antara pendidikan dengan keikutsertaan suami menjadi akseptor KB di Wilayah Desa Karangduwur Kecamatan Petanahan Kabupaten Kebumen Jawa Tengah dengan nilai sig $(0,130>0,05)$.

2) Ada hubungan yang signifikan antara jumlah anak dengan keikutsertaan suami menjadi akseptor KB di Wilayah Desa Karangduwur Kecamatan Petanahan Kabupaten Kebumen Jawa Tengah dengan nilai sig $(0,001<0,05)$.

3) Ada hubungan yang signifikan antara pendapatan dengan keikutsertaan suami menjadi akseptor KB di Wilayah Desa Karangduwur Kecamatan Petanahan Kabupaten Kebumen Jawa Tengah dengan nilai sig $(0,005<0,05)$.

4) Tidak ada hubungan yang signifikan antara pengetahuan dengan keikutsertaan suami menjadi akseptor KB di Wilayah Desa Karangduwur Kecamatan Petanahan Kabupaten Kebumen Jawa Tengah dengan nilai sig $(0,882>0,05)$.

\section{b. Saran}

1) Bagi Masyarakat

Meningkatkan pengetahuan dan kesadaran mengenai keikutsertaan suami menjadi akseptor KB sehingga menjadikan pertimbangan tersendiri dalam pensuksesan ber-KB.

2) Bagi Instansi Pelayanan Kesehatan

Dapat meningkatkan pelayanan kesehatan dalam pelaksanaan keluarga berencana bagi pria, khususnya dalam fasilitas pelayanan kesehatan yang masih belum memadai.

3) Bagi Peneliti Selanjutnya

Diharapkan dapat dijadikan sebagai penelitian lebih lanjut yang sejenis dengan mencari hubungan karakeristik suami dilihat dari faktor eksternal.

\section{DAFTAR PUSTAKA}

1. BKKBN, Keluarga Berencana, Kesehatan Reproduksi, Gender, dan Pembangunan Kependudukan, Jakarta. 2003a

2. Junaedi, Kesertaan KB Pria Masih Rendah, http://www.jatengprov.go.id, diambil Pada tanggal 25 April 2010, Yogyakarta. 2010

3. BKKBN, Peningkatan Partisipasi Pria Dalam Keluarga Berencana dan Kesehatan Reproduksi di Indonesia, Jakarta. 2003b 
4. Uly, Pencapaian program $K B$ di Jateng belum ideal, http:// www.wawasandigital.com, diambil pada tanggal 5 Juni 2010, Yogyakarta. 2010

5. Notoatmodjo, Metodologi Penelitian Kesehatan, Rineka Cipta, Jakarta. 2005

6. Notoatmodjo, S., Pendidikan dan Perilaku Kesehatan, Rineka Karya Cipta, Jakarta. 2003

7. Riadi, A.A., Beberapa Karakteristik Ibu Yang Berhubungan Dengan Pemakaian Tubektomi Pada Peserta KB Aktif Di Desa Kantonsari Kecamatan Demak Kota Kabupaten Demak Bulan September Tahun 2001. Skripsi Fak IImu Kesehatan UMS. 2001 